傍鞍部内頝動脈溜の手術

一視神経の温存一

堀内 哲吉

信州大学医学部脳神経外科

\title{
Preservation of the Optic Nerve during Surgery for Paraclinoid Carotid Artery Aneurysm
}

Tetsuyoshi Horiuchi, M.D.

Department of Neurosurgery, Shinshu University School of Medicine

Recently, endovascular interventions such as coil embolization and flow-diverting stenting are usually used to manage paraclinoid carotid artery aneurysms due to anatomical location and visual complications. However, all paraclinoid carotid artery aneurysms cannot be treated with the endovascular approach. To prevent visual complications, clipping surgery for paraclinoid carotid artery aneurysm, skull base technique, retrograde suction decompression method, intraoperative electrophysiological monitoring, and indocyanine green videoangiography have been developed. In this report, the functional anatomies of the ophthalmic artery and the superior hypophyseal artery feeding the optic apparatus and originating from the paraclinoid carotid artery are summarized. Moreover, the direct surgical procedure used for paraclinoid carotid artery aneurysm is presented.

(Received November 26, 2018; accepted December 17, 2018)

Key words : aneurysm, clipping, ophthalmic artery, superior hypophyseal artery, paraclinoid carotid artery aneurysm

Jpn J Neurosurg（Tokyo）28：391-397, 2019

\section{はじめに}

傍鞍部内頝動脈瘤は，血管内で治療される頻度が増加 しクリッピング症例は減少している（Fig. 1)。この最大 の理由として，フローダイバーターをはじめとする血管 内治療機器の進歩が著しいことが挙げられる。 また，直 達手術においては複雑な局所解剖の知識が必要であるこ とに加えて，視症状の出現や悪化が高率に起こることも 理由であると思われる。しかし，血管内治療では再発の 問題や完全閉塞率が低いなどの問題が未解決である。さ
らに血栓化動脈瘤などの占拠性病変や造影剂アレルギー 症例などにおいては，今後も直達手術が必要な症例も存 在する。最近では，視覚誘発電位（visual evoked poten-

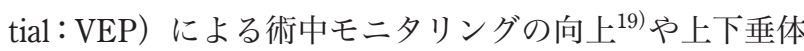
動脈（superior hypophyseal artery：SHA）の機能解剖理 解により ${ }^{6) 899)}$, 直達手術においても視症状合併症の低下 ならびに予防が可能となってきている，本稿では，視神 経・視交叉機能を温存するための傍鞍部血管解剖と傍鞍 部内頝動脈瘤治療の実際について概説する.

連絡先：堀内哲吉, $\overline{7} 390-8621$ 松本市旭 3-1-1 信州大学医学部脳神経外科

Address reprint requests to: Tetsuyoshi Horiuchi M.D., Department of Neurosurgery, Shinshu University School of Medicine, 3-1-1 Asahi, Matsumoto-shi, Nagano, 390-8621, Japan 


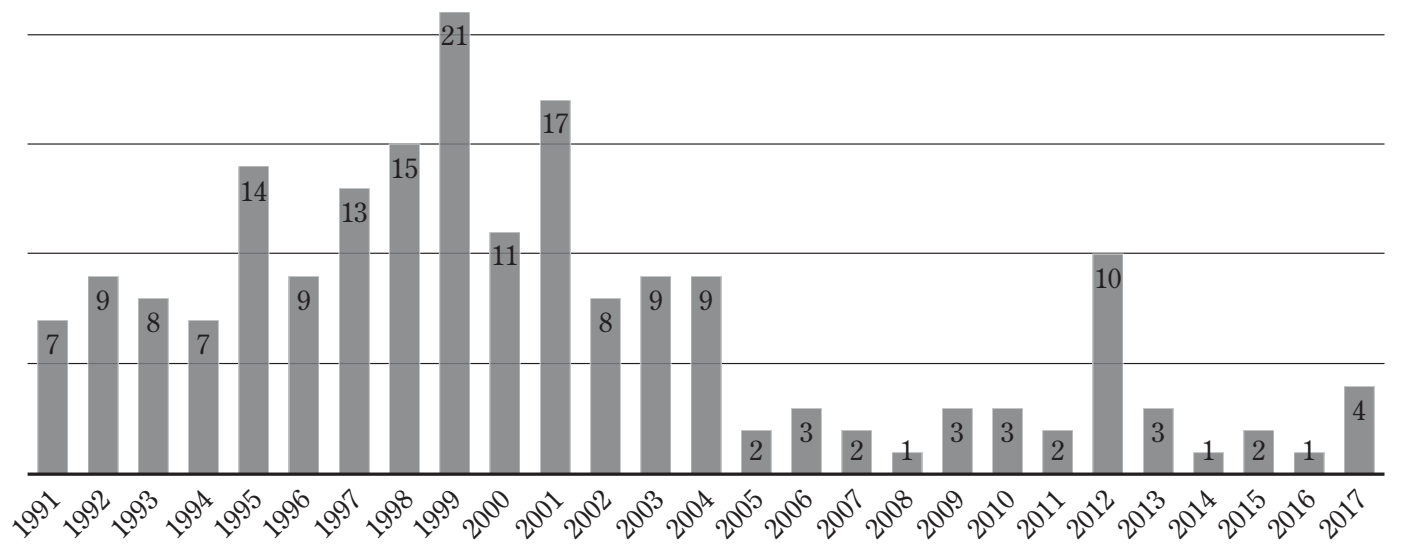

Fig. 1 Bar graph showing the number of clipping surgeries performed at Shinshu University Hospital between 1991 and 2017

\section{視症状合併症の頻度と原因}

傍鞍部内頝動脈瘤クリッピング術における視症状の出 現や悪化は, 最大で約30\%程度といわ扎ている91913)1620). この視症状には，自覚的な症状はないものの, 眼科視野 検査にて視野欠損が発見されるような軽度のものも含ま れるが，大きな問題である. 出現時期として, 術直後に 出現するものが多いが，術後しばらくしてから出現する ものもあることが知られている ${ }^{16)}$. 視症状合併の危険因 子としては，前床突起削除，動脈瘤石灰化，動脈溜サイ ズなどが報告されている。視症状出現・悪化の原因とし て(1)視神経・視交叉に対する手術操作による視神経自体 の損傷，(2)前床突起削除や視神経管の開放に用いるドリ ルや超音波手術機器による熱または振動による損傷, (3) 視神経・視交叉・視索などの血流障害，(4)炎症反応，(5) フィブリン糊などに対するアレルギー反応などが考えら れる，現在では，手術中に原因を特定する方法は存在し ない．視機能温存のために(1)内視鏡を用いた病変の視認 や確認，(2VEPを用いた術中モニタリング，(3)インドシ アニングリーン（ICG）蛍光血管撮影などによる血流の 確認などが行われている。これらの方法により視機能温 存の治療成績は向上してきているが，原因が特定できな い視力・視野障害をときに経験する。

原因が特定できない手術に伴う視症状の出現・悪化に 関して，視神経・視交叉の血流障害が一因として考えら れる。頭蓋内視神経・視交叉の血流は, 眼動脈・SHA • 前交通動脈・前大脳動脈・後交通動脈が複雑に関与して いる．傍鞍部内頝動脈瘤直達手術時に問題となる眼動脈 と SHA について以下に解説する。

\section{眼動脈}

眼動脈は, 視神経の下方で distal dural ring を貫通した 直後の内頝動脈内側壁より分岐する（Fig. 2)。よって眼 動脈分岐後に存在する動脈瘤は基本的に硬膜内病変であ る. 眼動脈は, 分岐直後に外側方向へ走行し視神経下面 で視神経と伴走して視神経管から眼窩内に至る(Fig. 2)。 眼動脈は基本的に硬膜内分岐であるが， distal dural ring 内分岐や硬膜外分岐のあることもよく知られている(4)14). 傍鞍部内頝動脈瘤直達治療における検討では，硬膜内分 岐が 85.7\%, 硬膜外分岐が 7.6\%, distal dural ring 内分岐 が 6.7\%であった ${ }^{4)}$. Distal dural ring を切離し内䅡動脈の 可動性を得ることは，傍鞍部内頝動脈瘤直達手術におい て必要な手技であるが，このバリエーションがあること を知っていないと眼動脈損傷の危険性がある.

視神経の血流支配は，眼窩内，視神経管内，頭蓋内の $3 つ の$ 部位に分類される ${ }^{3)}$. 眼窩内の視神経は, 眼動脈な らびに中硬膜動脈を代表とする外頝動脈の分枝より栄養 されている，視神経管内視神経は，眼動脈からの細かな 分枝により栄養されている。頭蓋内視神経は，上面は前 大脳動脈より，下面はSHA により血流供給を受けてい る.

眼動脈閉塞により視症状が出現することはまれである といわれているが，その根拠となっているのは，Johnson と Walker が発表した 1951 年の古い論文である ${ }^{11)}$ 。現在 でもこの論文が，眼動脈と視神経虚血の関係について引 用されている。論文では，総頚動脈または内頝動脈閉塞 例の 107 例において永続的に失明を認めたのは, 11 症例 (10.3\%) であったと報告している。これにより，引用論 

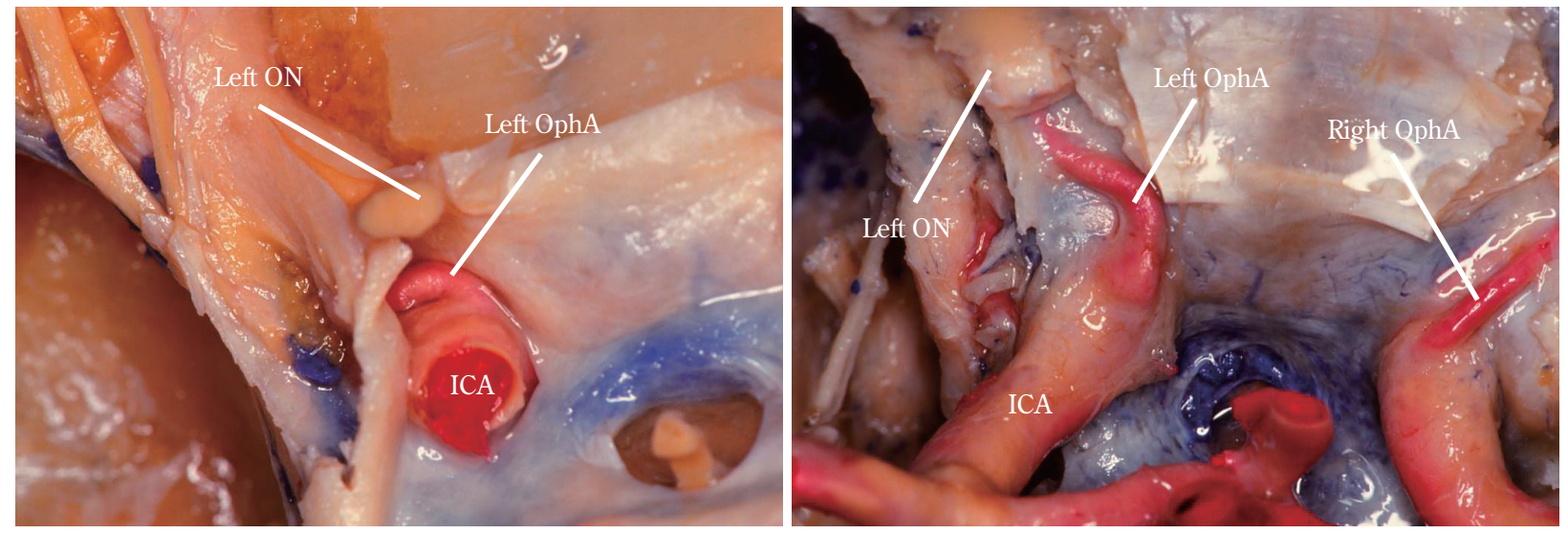

Fig. 2 Anatomy of the ophthalmic artery (dorsal view)

ICA : internal carotid artery, $\mathrm{ON}$ : optic nerve

文の多くは眼動脈が閉塞しても $90 \%$ の症例は失明しな いと記載している。 しかし，この報告は半盲などの視野 障害や視力低下などには言及しておらず問題があると思 われる。最近の報告として, 眼動脈の一時閉塞を施行し て血管撮影で検討したものがある ${ }^{1)}$. 14 症例に眼動脈の 一時閉塞を血管内で行い, 外䅡動脈経由の側副血行路に よる網膜血流があるかどうかを検討している。 12 例 (85.7\%) において側副血行路による血流が確認できたと のことであり, 多くの症例では眼動脈分岐直後の閉塞で は, 網膜虚血になる可能性は低いことになる。しかし, 眼動脈血流低下や血管内治療後塞栓症による網膜虚血は まれでないとされる。傍鞍部内頝動脈瘤治療において眼 動脈起始部を含む内頝動脈にフローダイバーターを留置 した検討では，85.7\%の症例で眼動脈の血流は維持され ていたが，35.7\%の症例で視症状の合併症を認めたとの 報告がある ${ }^{17)}$. 特に眼動脈が動脈瘤体部より分岐する症 例では, $80 \%(4 / 5)$ の症例に網膜塞栓症を合併した。そ の理由として動脈瘤内の血栓が，眼動脈内に流入したこ とが考えられた。また，10.7\%の症例に視神経萎縮を合 併した。この原因として著者らは, 急激な眼動脈血流低 下を挙げている。 つまり, 狭窄が進行して眼動脈血流が 徐々に低下するような場合は側副血行路が発達してくる が，急激な血流低下は問題となる可能性があることを示 している.

以上のことより，10〜 $15 \%$ の症例では急激な眼動脈閉 塞により, 視症状出現の危険性があることが推察され る.よって, 傍鞍部内頝動脈瘤クリッピング治療におい て, 視症状の合併症を防止するためには, 眼動脈の温存 に努めるべきである.

\section{SHA}

SHA は, 硬膜内の carotid cave から後交通動脈分岐部 までの内䅡動脈内側部より分岐する細動脈である ${ }^{46)}$ () . Carotid cave は distal dural ringより心臟側に位置する硬 膜内のポケット (carotid collar と内頝動脈の間にある空 間) であるため ${ }^{15)}$, 眼動脈より心臟側に位置している. SHA は発生学的に重要な血管であるとされている. 太さ は $0.25(0.1 \sim 0.5) \mathrm{mm}$ 程度で, 片側 1〜 5 本存在する ${ }^{2) 69)}$. SHA は細い血管であるが，ときに視神経・視交叉の重要 な栄養血管のこともある。血管撮影でSHA は通常同定が 困難であり, バリエーションも豊富なため傍鞍部内頝動 脈瘤クリッピング治療においては SHA の局所解剖を理 解しておくことは重要である.

視交叉の血流支配は，上面と下面に分けて分類されて いる ${ }^{18)}$ ，上面は，前大脳動脈，前交通動脈ならびに SHA から血流があり，下面はSHA と後交通動脈からの血流が ある。これらの血管は，上面と下面それぞれに豊富な吻 合があり，また上面と下面の間にも吻合があるとされて いる ${ }^{18)}$. また，両側の SHA は下垂体柄周囲で吻合してい るため（Fig. 3), 内頝動脈分岐直後の閉塞では視交叉に 虚血を惹起する可能性は低( ${ }^{9}$ 。 しかし, 両側の SHA 閉 塞は虚血を惹起するので注意が必要である ${ }^{9)}$. SHA は視 交叉上面にも一部血流を供給しているが，主には下面か らのものである。このため, 動脈瘤直達手術においては SHA の吻合程度は, 直接観察できない。また, opticocarotid space が㹨い症例では，SHA 自体の観察も困難で ある. Contralateral approach（Fig.4）では, ipsilateral approach よりも SHA は観察しやすいがやはり下面まで は観察できない. よって, 直達手術において, どの SHA 


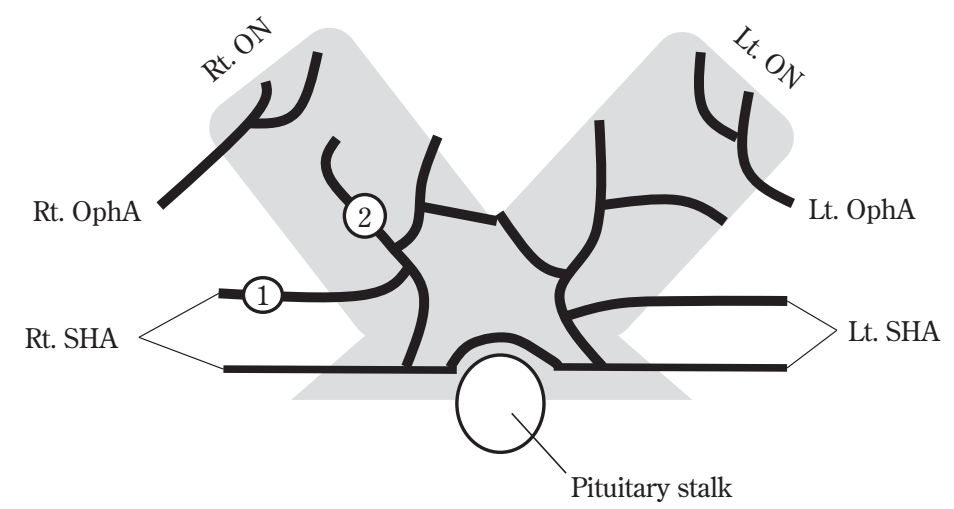

Fig. 3 Image showing the vascular network of ophthalmic artery and superior hypophyseal artery (SHA) at the optic nerve and chiasma (ventral view). Occlusion of the SHA at 1 and 2 did not cause ischemia and ischemia of optic nerve or chiasma, respectively.

$\mathrm{Rt}:$ right, $\mathrm{Lt}:$ left
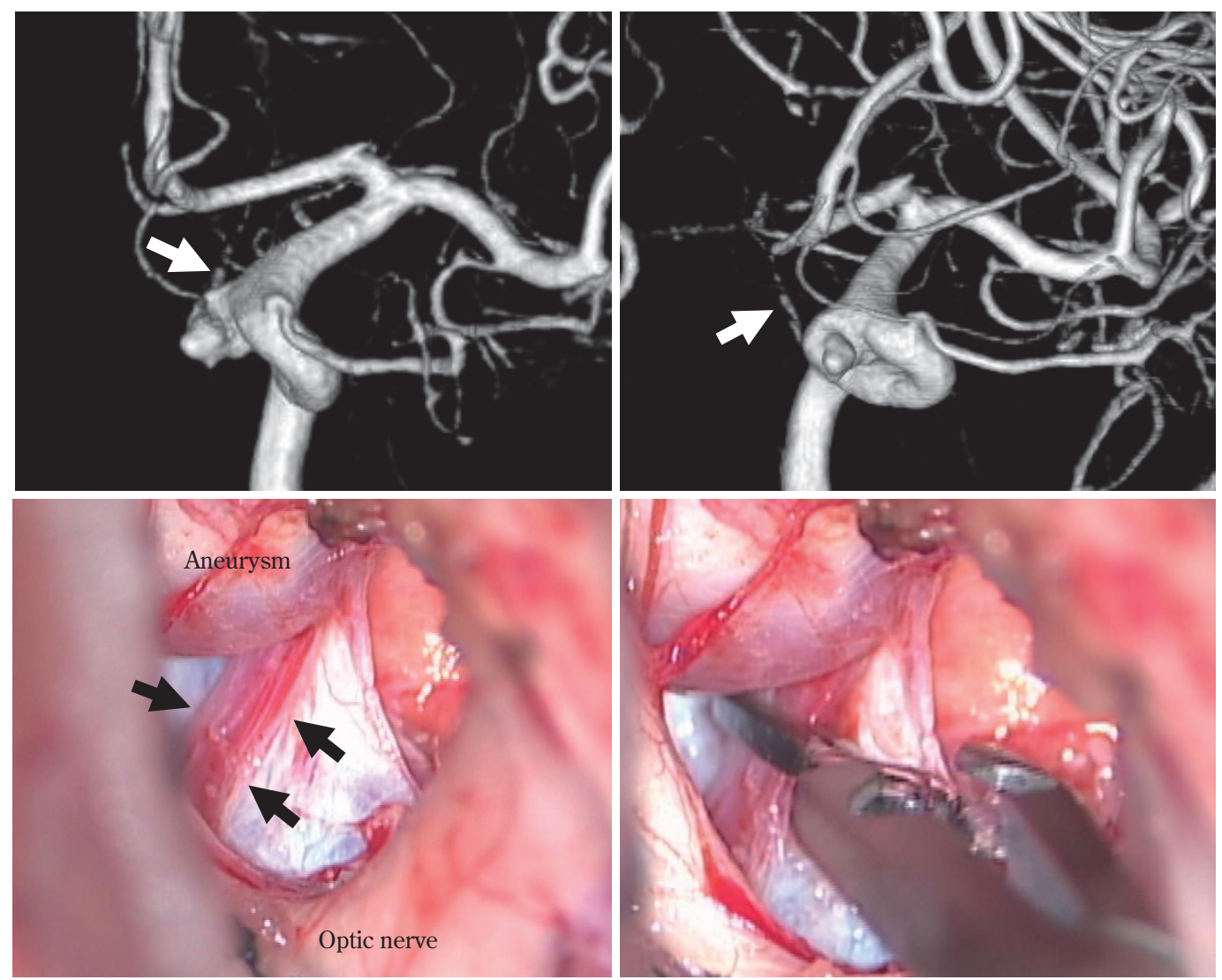

Fig. 4 Intraoperative temporary occlusion of the hypophyseal artery (SHA)

Preoperative rotational angiography (upper column) and intraoperative photographs of the aneurysm through the contralateral approach (lower column) showing the SHA aneurysm and SHA itself (arrows).

が重要なのかを判断するのは困難である. SHA 動脈瘤の SHA 分岐はさまざまであり温存が困難な症例も存在す る (Fig. 5)。よって, 術中に SHA の血流温存が難しい症
例では SHA 閉塞試験が必要となる $(\text { Fig. 4 })^{9)}$ 10). 内頝動 脈分岐直後の片側性 SHA閉塞は, 豊富な側副血行路があ るため視交叉への虚血を惹起する可能性は低いと思われ 
$ろ^{9)}$.

SHA 閉塞が原因と思われる, 血管内治療後の視野障害 合併症例が報告されている ${ }^{12)}$. 症例はSHA動脈瘤に対し て Onyx を用いて，塞栓術を施行した症例である．液体 塞栓物質によりSHA 自体とその吻合部位まで閉塞され たことが，視野障害の原因と思わ机た，MRIにて視交叉 に虚血巣が出現している。

\section{手術の実際}

ここでは，実際に行っている傍鞍部内頝動脈瘤クリッ ピング方法について紹介する.

セットアップ：われわれは，傍鞍部内頝動脈瘤を(1)眼 動脈分岐部動脈瘤, (2)SHA 動脈瘤, (3)carotid cave 動脈 瘤, (4)前壁 (“背側”) 動脈瘤, (5)その他, と5 種類に分

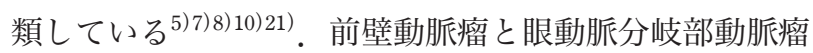
は，動脈瘤ならびに内頝動脈の視認が比較的容易である ので ICG 蛍光血管撮影のみで十分なことが多い. 一方, SHA 動脈瘤や carotid cave 動脈瘤では, 有㝕クリップ先 端の確認が難しいことや内頝動脈狭窄が起こることがあ り，術中血管撮影の適応となることがある。また， suction decompression を用いるような大型動脈餾でも術中 血管撮影が必要であり, ハイブリッド手術室が使用可能 な施設であれば，同手術室での治療が推奨される。

傍鞍部内頝動脈瘤直達手術では頝部内頝動脈確保を ルーチンで行っている。これは, proximal controlの意味 と動脈瘤剝離時に一時閉塞し動脈瘤圧を低下させ㓦離を 容易にできるメリットがある。分岐部が高位で頝部内頝 動脈が確保困難な症例は, 総䅡動脈と外頚動脈を確保す る. 総䅡動脈のみでは, 外䅡動脈からの逆行性血流で proximal controlにならないことがあり注意が必要である.

開 頭: 基本的に trans-sylvian approach より subfrontal approach であるため正中側に大きめの開頭が必要であ る。特に contralateral approach では内側に大きな開頭が 必要となる。一時的な虚血が危惧される症例では, 浅側 頭動脈中大脳動脈吻合術を先行させる.

前床突起削除：われわれは，硬膜内より前床突起削除 を行っている(1022). 最大のメリットは, 必要な部分のみ の削除で済むことである. 硬膜内より, 動脈瘤と前床突 起の関係を把握してクリッピングに必要な骨削除を行 う。前床突起の大きさには個人差が大きく, 視神経管開 放や optic strut 削除に関しては不要な症例もあるので, 硬膜内削除は理にかなった方法である。この操作は視症 状合併症出現に関与する可能性があるため, より慎重な 操作が必要である。ドリルか超音波手術機器で削除する

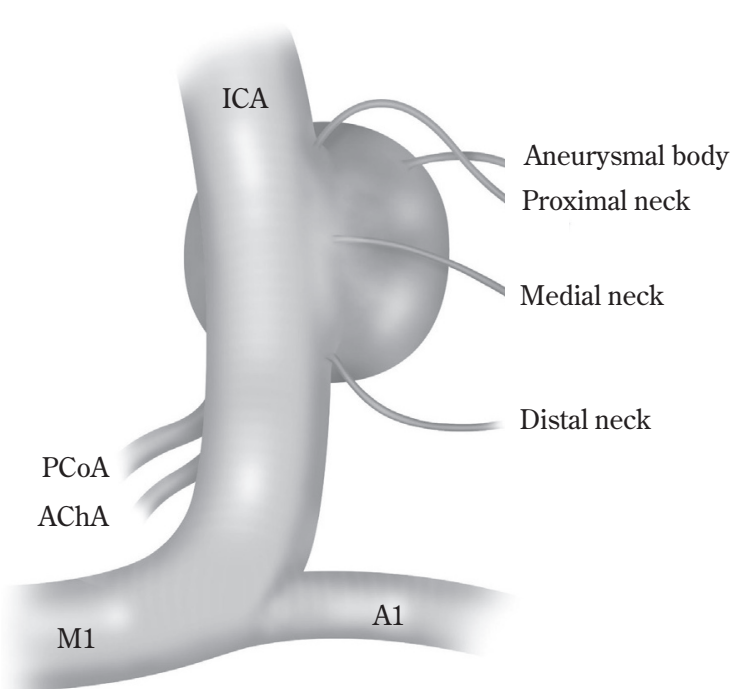

Fig. 5 Image showing the relationship between the hypophyseal artery (SHA) aneurysm and SHA itself. The SHA branching from the proximal neck, medial neck, distal neck, and aneurysmal body.

$\mathrm{PCoA}$ : posterior communicating artery, AChA : anterior choroidal artery

ことが一般的であるが，より安全性の高い超音波手術機 器を打锥めする。超音波手術機器使用によるデメリット は，ドリル使用より削除時間がかかることなどが挙げら れる。超音波手術機器でも熱損傷は起こるので十分な洗 浄は必要である.

Distal dural ring 切離: 通常の硬膜内傍鞍部内䅡動脈瘤 治療では, distal dural ring 切離が必要になる. 前壁動脈 瘤や眼動脈分岐部動脈瘤では, 切離する範囲は短い。一 方, SHA 動脈瘤では全周性に切離が必要なことが多い.

眼動脈・SHA の一時閉塞 : 眼動脈分岐部動脈瘤治療にお いて，術中に眼動脈を 10 分程度一時閉塞して，VEP 変 化が惹起されるかどうかを検討しているが（Fig. 6)，現 時点ではVEP変化を 1 例も経験していない. 症例数がま だ少ないため，今後もさらなる検討が必要である。眼動 脈は前述したとおり, 視神経管内の唯一の血流供給血管 であることと，遅発性虚血の可能性が否定できないため 温存に努めている。一方，SHA 動脈留でもSHAの一時 閉塞を施行しているが（Fig. 4), VEP 変化のない症例で は complete clipping を優先している. 眼動脈に比して, SHA は細く複数本存在するため, 温存可能な SHA と温 存できないSHA 分岐形態がある（Fig. 5).

クリッピング：大型の SHA 動脈留では有空クリップを 用いる必要がある。有空クリップは有用であるが，微調 整が難しい，有空クリップのアプライ時には，視神経・ 視交叉にクリップ自体が接触することが多いので，視症 

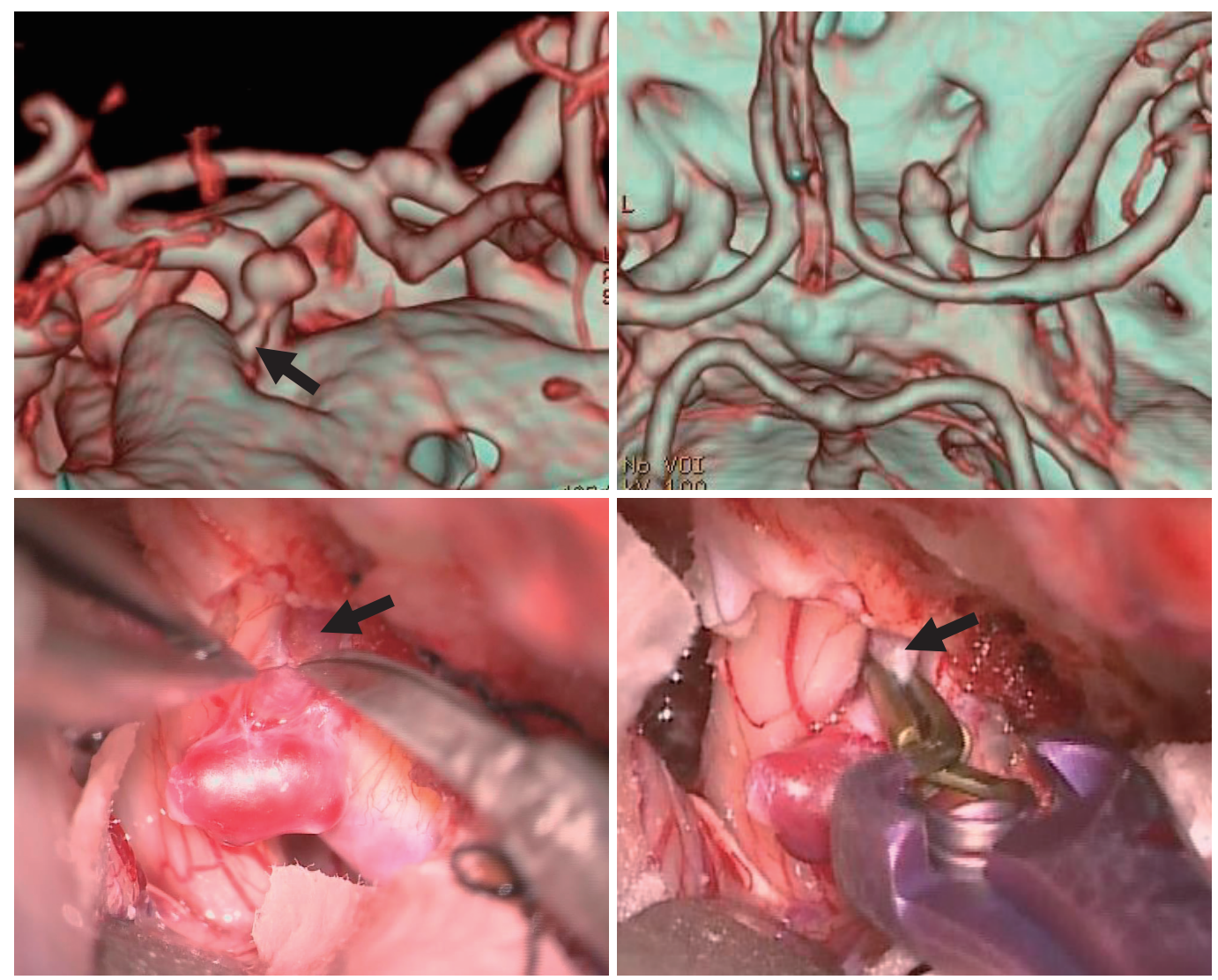

Fig. 6 : Intraoperative temporary occlusion of the ophthalmic artery (OphA). Preoperative threedimensional computed tomographic angiography (upper column) and intraoperative photographs (lower column) showing the carotid-ophthalmic aneurysm and OphA (arrows).

状の合併症回避には，安易な有空クリップ使用は控える べきと思われる。

\section{おわりに}

傍鞍部内頝動脈瘤直達治療における眼動脈・SHA の局 所解剖と実際の手術方法について概説した。この小論 が，読者の手術手技向上につながれば幸いである。

$\mathrm{COI}$ : 著者は日本脳神経外科学会への COI 自己申告の登録 を完了しています。本論文に関して開示すべきCOI はありま せん.

\section{文 献}

1) Ahn JH, Cho YD, Kang HS, Kim JE, Cho WS, Jung SC, Kim $\mathrm{CH}$, Han $\mathrm{MH}$ : Endovascular treatment of ophthalmic artery aneurysms : assessing balloon test occlusion and preservation of vision in coil embolization. AJNR Am J Neuroradiol $35: 2146-2152,2014$.
2) Gibo H, Lenkey C, Rhoton AL Jr: Microsurgical anatomy of the supraclinoid portion of the internal carotid artery. $J$ Neurosurg 55:560-574, 1981.

3) Hendrix P, Griessenauer CJ, Foreman P, Shoja MM, Loukas M, Tubbs RS : Arterial supply of the upper cranial nerves : a comprehensive review. Clin Anat $27:$ 1159-1166, 2014.

4) Horiuchi T, Tanaka Y, Kusano Y, Yako T, Sasaki T, Hongo K : Relationship between the ophthalmic artery and the dural ring of the internal carotid artery. Clinical article. J Neurosurg 111: 119-123, 2009.

5) Horiuchi T, Kusano Y, Yako T, Murata T, Kakizawa Y, Hongo $\mathrm{K}$ : Ruptured anterior paraclinoid aneurysms. Neurosurg Rev 34: 49-55, 2011.

6）堀内哲吉, 本郷一博：SHA，波出石弘，石川達哉，田中 美千裕編：脳動脈コンプリート一開頭手術と血管内治療 のために。東京, 中外医学社, 2014, pp.30-36.

7）堀内哲吉, 柿澤幸成, 本郷一博：内頝動脈瘤（近位部）の 解剖。宝金清博監, 井川房夫, 宮地 茂編：内頝動脈瘤 (ICA Aneurysm) のすべて一近位部（cavernous-paraclinoid）：シミュレーションで経験する手術・IVR/92 本の WEB 動画付き．大阪，メディカ出版，2015, pp.7-11.

8）堀内哲吉, 本郷一博：シミュレーションと手術の実際 IC paraclinoid 下内側向き（SHA）。宝金清博監，井川房夫， 宮地 茂編: 内頝動脈瘤 (ICA Aneurysm) のすべて一近 
位部 (cavernous-paraclinoid)：シミュレーションで経験 する手術・IVR/92 本の WEB 動画付き. 大阪, メディカ 出版, 2015, pp.128-134.

9) Horiuchi T, Goto T, Tanaka Y, Kodama K, Tsutsumi K, Ito K, Hongo $\mathrm{K}$ : Role of superior hypophyseal artery in visual function impairment after paraclinoid carotid artery aneurysm surgery. J Neurosurg $123:$ 460-466, 2015.

10) Horiuchi T, Yamamoto Y, Suzuki Y, Kobayashi M, Ichinose S, Hongo $\mathrm{K}$ : Clipping surgery for paraclinoid carotid aneurysm. Acta Neurochir Suppl 123: 27-32, 2016.

11) Johnson $\mathrm{HC}$, Walker $\mathrm{AE}$ : The angiographic diagnosis of spontaneous thrombosis of the internal and common carotid arteries.J Neurosurg 8:631-659, 1951.

12) Johnson JN, Elhammady M, Post J, Pasol J, Ebersole K, AzizSultan MA : Optic pathway infarct after Onyx HD 500 aneurysm embolization: visual pathway ischemia from superior hypophyseal artery occlusion. J Neurointerv Surg 6: e47, 2014.

13) Kamide T, Tabani H, Safaee MM, Burkhardt JK, Lawton MT : Microsurgical clipping of ophthalmic artery aneurysms : surgical results and visual outcomes with 208 aneurysms. J Neurosurg 129: 1511-1521, 2018.

14) Kyoshima $\mathrm{K}$, Oikawa $\mathrm{S}$, Kobayashi $\mathrm{S}$ : Interdural origin of the ophthalmic artery at the dural ring of the internal carotid artery. Report of two cases.J Neurosurg 92:488-489, 2000.

15) Kobayashi S, Kyoshima K, Gibo H, Hegde SA, Takemae T, Sugita K : Carotid cave aneurysms of the internal carotid artery. J Neurosurg $\quad \mathbf{7 0}: 216-221,1989$.

16) Matsukawa $H$, Tanikawa $R$, Kamiyama $H$, Tsuboi $T$, Noda $K$,
Ota N, Miyata S, Takeda R, Tokuda S : Risk factors for visual impairments in patients with unruptured intradural paraclinoid aneurysms treated by neck clipping without bypass surgery. World Neurosurg 91: 183-189, 2016.

17) Rouchaud A, Leclerc O, Benayoun Y, Saleme S, Camilleri $Y$, D’Argento F, Boncoeur MP, Robert PY, Mounayer C : Visual outcomes with flow-diverter stents covering the ophthalmic artery for treatment of internal carotid artery aneurysms. AJNR Am J Neuroradiol $36: 330-336,2015$.

18) Salaud C, Ploteau S, Blery P, Pilet P, Armstrong O, Hamel $\mathrm{A}$ : Extrinsic and intrinsic blood supply to the optic chiasm. Clin Anat $31:$ 432-440, 2018.

19) Sato A : Interpretation of the causes of instability of flash visual evoked potentials in intraoperative monitoring and proposal of a recording method for reliable functional monitoring of visual evoked potentials using a light-emitting device. J Neurosurg 125:888-897, 2016.

20) Shimizu T, Naito I, Aihara M, Fujimaki H, Asakura K, Miyamoto N, Yoshimoto $\mathrm{Y}$ : Visual outcomes of endovascular and microsurgical treatment for large or giant paraclinoid aneurysms. Acta Neurochir (Wien) 157: 13-20, 2015.

21) Tanaka Y, Hongo K, Tada T, Nagashima H, Horiuchi T, Goto T, Koyama J, Kobayashi S : Radiometric analysis of paraclinoid carotid artery aneurysms. J Neurosurg 96:649-653, 2002.

22) Tanaka Y, Hongo K, Tada T, Kakizawa Y, Kobayashi S : Protective dural flap for bone drilling at the paraclinoid region and porus acusticus - technical note. Neurol Med Chir (Tokyo) 43:416-418, 2003.

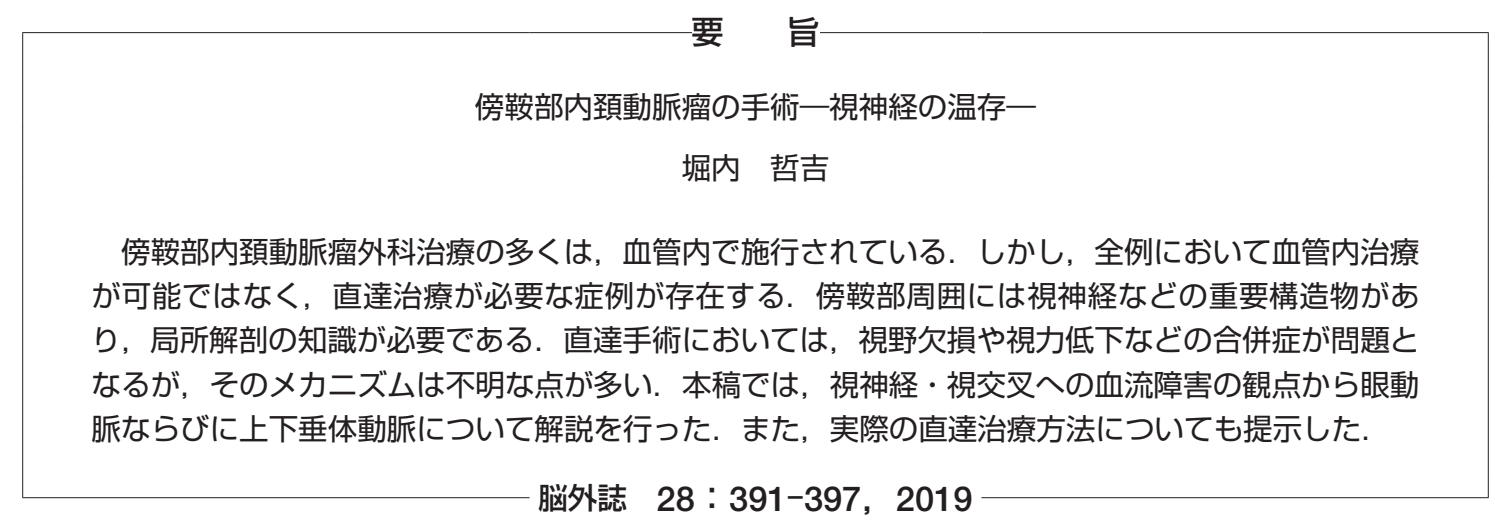

